\title{
KUALITAS JAJANAN ANAK SEKOLAH DASAR SECARA MIKROBIOLOGI DI KECAMATAN KOTO TANGAH PADANG SUMATERA BARAT
}

\author{
SNACKS QUALITY OF PRIMARY SCHOOL CHILDREN IN MICROBIOLOGY \\ STANDARD IN KOTO TANGAH DISTRICT PADANG WEST SUMATRA
}

\author{
Rahmawita ${ }^{1,2}$, Dwi Hilda Putri ${ }^{2}$, Linda Advinda ${ }^{2}$ \\ ${ }^{1}$ Badan Pengawasan Obat dan Makanan (BPOM) Padang, Sumatera Barat \\ 2 Jurusan Biologi FMIPA Universitas Negeri Padang \\ Korespondensi: Rahmawita. Email: rahmawitawita@yahoo.co.id
}

\begin{abstract}
ABSTRAK
Pangan jajanan merupakan sarana bagi anak-anak dalam pemenuhan kebutuhan kecukupan gizi, tetapi juga berisiko menimbulkan keracunan jika tidak higienis. Menurut Undang-Undang RI nomor 18 tahun 2012 tentang pangan menyatakan bahwa keamanan pangan adalah usaha mencegah pangan dari kontaminasi biologis, kimia dan fisik. Laporan kasus kejadian luar biasa (KLB) yang dikeluarkan oleh BPOM tahun 2016 menyatakan bahwa 16,35\% keracunan makanan di Indonesia berasal dari pangan jajanan di sekolah dan sebanyak 42,14\% berasal dari jajanan yang dibuat dari pangan rumah tangga. Tujuan penelitian ini adalah Untuk menguji kualitas jajanan anak sekolah dasar secara mikrobiologi di Kecamatan Koto Tangah Padang. Penelitian ini bersifat deskriptif untuk mengidentifikasi mikroba patogen dalam jajanan yang di jual pada 19 Kantin Sekolah Dasar pada bulan Maret hingga April 2018. Total sampel yang dapat disampling sebanyak 49 sampel. Pengambilan sampel dilakukan pagi hari hingga menjelang jam istirahat siang. Sampel yang disampling dari kantin dibagi dalam tiga bentuk yaitu jajanan kering, jajanan basah dan minuman yang diberi es batu. Hasil penelitian dengan ditemukannya S.aureus pengkontaminasi pada 1 sampel (2,04\%) dari jajanan kering dan E. coli sebanyak 3 sampel (6,12\%) dari minuman yang diberi es batu, dan bakteri jenis lain sebanyak $91.82 \%$.
\end{abstract}

Kata kunci: Kualitas Mikrobiologi, Jajanan Anak Sekolah, Mikroba Patogen Pengkontaminan.

ABSTRACT
School Children Food (SCF) played an important role in providing nutrient intake of children nutritional needs, in the other hand, it may has a risk of poisioning if unhygienic. According to the Law of Republic Indonesia number 18 of 2012 on food states that food security is an attempt to prevent food from biological, chemical and physical contamination. Report on Outbreaks issued by BPOM in 2016 states that 16.35\% of food poisoning in Indonesia caused by contaminated SCF, and as much as $42.14 \%$ caused by contaminated of household SCF. The aim of this study is to test the microbiological quality of Elementay SCF in Sub-district Koto Tangah Padang. This descriptive research would like to identify pathogenic microbial in SCF which sold at 19 elementary school canteen during periode of time March to April 2018. The total samples are 49. Time of sampling conducted from morning until right before lunchtime. The samples categorized into three forms which are dried, wet and ice-cubed drinks. The result showed that one sample (2.04\%) of dried SCF was contaminated by S. aureus, three samples (6.12\%) of Iced-cube drinks was contaminated by E.coli and the rest (91.82\%) was contaminated by other bacteria.

Keyword: Microbiological Quality, School Children Food, Pathogenic Bacteria.

\section{PENDAHULUAN}

Undang-undang No.36 Tahun 2009 tentang kesehatan telah mengamanatkan upaya perbaikan gizi untuk meningkatkan mutu gizi perorangan dan masyarakat. Pemenuhan kecukupan gizi anak dapat melalui sarapan dan pangan jajanan bagi anak yang belum sarapan.

Pangan jajanan anak sekolah merupakan panganan yang ditemui di sekolah dan secara rutin dikonsumsi oleh sebagian besar anak sekolah dalam pemenuhan kecukupan gizi (Badan POM RI., 2013). Jajanan anak sekolah tersebut memberikan kontribusi masing-masing sebesar $22,9 \%$ dan $15,9 \%$ terhadap keseluruhan asupan energi dan protein anak sekolah dasar (Pelczar et al., 2014). Keputusan 
Menteri Kesehatan Republik Indonesia Nomor 942/MENKES/SK/VII/2003 tentang persyaratan higiene sanitasi makanan jajanan, menyatakan bahwa makanan jajanan merupakan makanan dan minuman yang diolah di tempat penjualan atau disajikan langsung pada konsumen. UndangUndang RI nomor 18 tahun 2012 tentang pangan menyatakan bahwa salah satu aspek keamanan pangan yang harus diperhatikan adalah upaya untuk mencegah pangan dari kemungkinan cemaran biologis, kimia dan benda lain

Cemaran biologis biasanya terjadi karena makanan terkontaminasi oleh mikroba dan mengeluarkan eksotoksin menyebabkan keracunan bagi yang memakannya. Walaupun tidak selalu menimbulkan penyakit, namun akan mempengaruhi nilai gizi makanan (Okolie et al., 2012).

Bakteri pengkontaminan dalam makanan selain dapat menurunkan kualitas makanan, juga beresiko menimbulkan penyakit pada konsumen (SNI, 2009). Hal ini disebabkan kondisi sanitasi lingkungan, proses pengolahan dan peralatan yang digunakan tidak higienis

Terdapatnya bakteri pada pangan jajanan anak sekolah (PJAS) dapat disebabkan kondisi sanitasi lingkungan, proses pengolahan dan peralatan yang digunakan (Yunaenah, 2009) . Sanitasi peralatan dan higiene penjamah juga merupakan faktor penting dalam penyebaran bakteri (Vitria dan Deni., 2013).

Secara mikrobiologi, pangan jajanan yang tidak higienis, dapat mengandung bakteri patogen jenis Staphylococcus aureus dan Salmonella sp (Mirawati et al., 2014). Selain itujuga dapat ditemukan Escerichia coli, Bacilus cereus, dan Pseudomonas sp (Okolie et al., 2012). Penyakit yang disebabkan karena makanan atau minuman terkontaminasi oleh mikroba patogen disebut foodborne disease (Susanna dan Hartono, 2003). Foodborne disease umumnya disebabkan oleh Salmonella sp, Shigella dysenteriae, Staphylococcus aureus, Camphylobacter jejuni, Clostridium botulinum, Clostridium perfringens, E. coli, dan Listeria monocytogenes (WHO, 2004). Selain itu mikroba pengkontaminan pangan lain Salmonella, Vibrio parahemolyticus, B. cereus, Proteus sp, dan cendawan (Irianto, 2006).

Depkes (1997) menyatakan, penyakit yang ditimbulkan bakteri melalui makanan, terjadi karena kontaminasi silang, penjamah makanan dan melalui hewan dan serangga. Mikroba pengkontaminan pangan biasanya masuk kedalam tubuh melalui saluran pencernaan.

\section{METODE}

Jenis penelitian ini adalah deskriptif. Peneliti mendeskripsikan bagaimana kualitas mikrobiologi dan jenis pengkontaminan yang dominan mengkontaminan jajanan anak sekolah dasar di Kecamatan Koto Tangah Padang.

\section{Alat dan Bahan}

Alat yang digunakan dalam penelitian tahap pembuatan dan sterilisasi meliputi autoklaf, Elenmeyer $250 \mathrm{~mL}, 300 \mathrm{~mL}, 500 \mathrm{~mL}$ dan 1000 $\mathrm{mL}$, neraca, $\mathrm{pH}$ meter, Hot plate stirrer, pipet takar $3 \mathrm{~mL}, 5 \mathrm{~mL}$, dan $10 \mathrm{~mL}$, dan petridis. Tahap pengerjaan sampel menggunakan Laminar Air Flow, stomacher, pipet takar, vortex mixer, ose, pipet elektronik dan tip.

Bahan yang digunakan terbagi atas media cair dan media padat dan satu set pewarnaan Gram. Media cair untuk uji $S$. aureus adalah Pepton Dilution Fluid (PDF), Triptic Soy Broth (TSB), media padatnya Baird Parker Agar (BPA), Tryptic Soy Agar (TSA), plasma EDTA dan kit Analisa Profile Indeks (API) Staph. Media untuk uji Salmonella adalah Buffered Pepton Water(BPW), Muller Kauffmann Tetrathionate Novobiocin broth (MKTTn ), Rappaport and Vassiliadis(RVS), dan media padatnya Brilliant Green Agar(BGA) serta kit API 20 E. Media untuk uji MPN E. coli berupa Mac Conkey Broth (MCB), E.Coli Broth (ECB), Pepton Dilution Fluit (PDF ), Eosin Methylen Blue Agar (EMB), TSA dan kit API 20 E . Media untuk uji B. cereus adalah BPBDW ( Butterfield Phospate Buffered Dilution Water ), TSB Polymyxin, MYP (Mannitol Egg Yolk Polymyxin Agar), TSA, Bacillus cereus Selective Supplement, Tellurit, egg yolk dan kit API $50 \mathrm{CH}$ dan bakteri E. coli ATCC 25922, S.aureus ATCC 6538, Salmonella typhimurium ATCC 14028 dan B. cereus ATCC 11778 sebagai kontrol positif.

\section{Prosedur Penelitian}

a. Sterilisasi alat

Peralatan gelas disterilkan menggunakan oven pada suhu $180^{\circ} \mathrm{C}$ selama 2 jam. Media disterilkan menggunakan autoklaf sesuai petunjuk packinga pada media. 


\section{HASIL DAN PEMBAHSAN}

Pemeriksaan jajanan anak sekolah ini dengan mengikutsertakan kontrol positif menggunakan E. coli ATCC 25922, S.aureus ATCC 6538, Salmonella typhimurium ATCC 14028 dan B. cereus ATCC 11778. Untuk uji biokimia menggunakan API setelah dilakukan pewarnaan Gram terlebih dahulu.

Hasil pemeriksaan ditemukan 8,14 \% bakteri patogen mengkontaminasi jajanan dengan jenis $E$. coli dan $S$. aureus, sedangkan $B$. cereus dan Salmonella tidak ditemukan. Selain bakteri patogen, bakteri lain juga ditemukan 91,84\% mengkontaminasi PJAS antara lain adalah $B$. thuringensis yang tumbuh dalam media MYP serta jenis bakteri lain yang tumbuh subur dalam media EMB, BGA dan BPA.

Bakteri lain pengkontaminasi PJAS tersebut dapat berasal dari lingkungan, bahan baku atau dari penjamah meliputi sanitasi, peralatan, higiene pedagang dan pengolahan ${ }^{4}$.

Hasil analisa ditampilkan dalam bentuk tabel sebagai berikut :

1. Persentase Pangan Jajanan pada 19 kantin

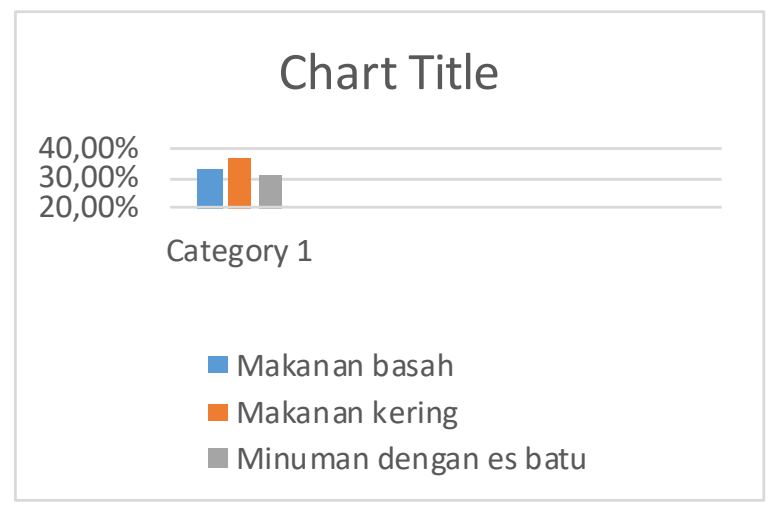

2. Jenis Bakteri Pengkontaminan yang Terdapat Pada Jajanan Anak Sekolah Dasar.

Tabel 1. Persentase Bakteri Yang Ditemukan Dalam Pangan Jajanan Anak Sekolah

\begin{tabular}{ccc}
\hline $\begin{array}{c}\text { Jenis Bakteri } \\
\text { Pengkontaminasi }\end{array}$ & $\begin{array}{c}\text { Jumlah } \\
\text { sampel }\end{array}$ & Persentase (\%) \\
\hline E. coli & 3 & 6,12 \\
S. aureus & 1 & 2,04 \\
Salmonella & 0 & 0 \\
B.cereus & 0 & 0 \\
Bakteri lain & 45 & 91,84 \\
Jumlah & 49 & 100 \\
\hline
\end{tabular}

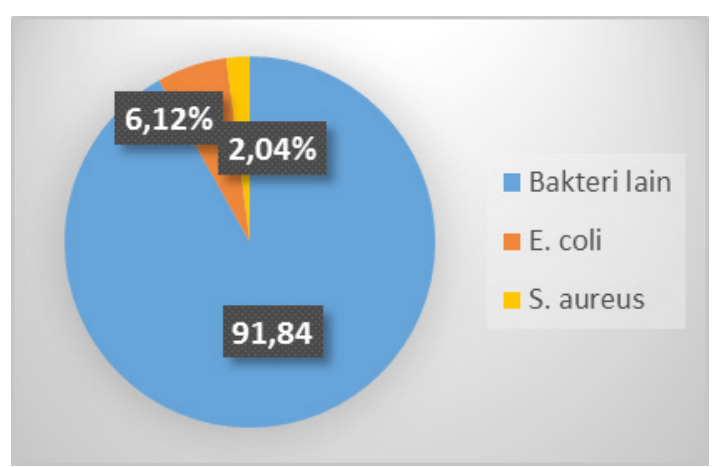

Pengambilan sampel dilakukan pada pagi hari sebelum jam istirahat, ditemukan pada hasil pemeriksaan bahwa E. coli lebih mendominasi dibanding S. Aureus, sedangkan B.cereus dan Salmonella tidak mendominasi pengkontaminan dalam pangan jajanan anak sekolah.

3. Hasil Kualitas Mikrobiologi Jajanan Anak Sekolah Dasar .

Tabel 2. Persentase Pangan Jajanan Anak Sekolah Yang Dijual Di 19 Kantin Sekolah Dasar Yang Terkontaminasi E. Coli

\begin{tabular}{ccccccc}
\hline $\begin{array}{c}\text { Kontaminasi } \\
\text { E. coli }\end{array}$ & $\begin{array}{c}\text { Makanan } \\
\text { basah }\end{array}$ & Persentase & $\begin{array}{c}\text { Makanan } \\
\text { kering }\end{array}$ & Persentase & $\begin{array}{c}\text { Minuman } \\
\text { dengan Es } \\
\text { batu }\end{array}$ & Persentase \\
\hline $\begin{array}{c}\text { Terkontaminasi } \\
\begin{array}{c}\text { Tidak } \\
\text { terkontaminasi }\end{array}\end{array}$ & 0 & 0 & 0 & 0 & 3 & 6,12 \\
\hline
\end{tabular}


Hasil pemeriksaan dari jajanan anak sekolah adalah ditemukannya $E$. coli dan $S$. aureus yang merupakan bakteri penyebab keracunan makanan. Walaupun E. coli dan $S$. aureus ditemukan dalam jumlah sedikit dari total sampel yang diperiksa, tetap saja akan mempengaruhi kualitas jajanan secara mikrobiologi karena akan dapat menyebabkan keracunan.

E. coli merupakan flora normal usus dan dapat dijumpai pada jaringan tubuh lain. Keberadaan bakteri ini di dalam makanan dan minuman merupakan petunjuk adanya bakteri patogen lain yang dapat menyebabkan tiphus, muntah dan diare (Majumdar et al, 2018).

Suhu merupakan salah satu faktor yang mempengaruhi pertumbuhan dan perkembangan bakteri. Dengan pemanasan mendidih selama beberapa menit, akan membunuh bakteri, tetapi tidak untuk menghancurkan toksinnya (Mirawati et al., 2014).

Kontaminasi makanan dan minuman oleh E.coli dapat disebabkan karena dua faktor yaitu faktor intrinsik dan faktor ekstrinsik. Faktor intrinsik seperti kandungan nutrisi, $\mathrm{pH}$, potensi redoks, dan aktivitas air. yang mempunyai hubungan dengan faktor ekstrinsik, seperti suhu, kelembaban relatif, dan atmosfer gas, akan menyebabkan terjadinya kontaminasi tersebut, sehingga perlu dilakukan kontrol kualitas yang ketat terhadap makanan (Kuswiyanto, 2017).

Selain faktor intrinsik dan ekstrinsik pengolahan yang menggunaan peralatan yang tidak dicuci dengan bersih dan menyimpan peralatan yang tidak layak mempunyai hubungan dengan kehadiran bakteri ini. Faktor lain adalah bahan baku air yang digunakan haruslah memenuhi syarat kesehatan (Pelczar et al., 2014).

Sesuai Kepmenkes RI nomor 942/ Menkes/SK/VII/2003 pasal 4 tentang Pedoman Persyaratan Hygiene Sanitasi Makanan Jajanan menyatakan bahwa air yang digunakan dalam penanganan makanan jajanan harus memenuhi syarat kesehatan (Jawetz, 2008)

Nilai MPN E.coli yang didapat pada hasil penelitian ini $43 \mathrm{MPN} / \mathrm{mL}, 93 \mathrm{MPN} / \mathrm{mL}$ dan $460 \mathrm{MPN} / \mathrm{mL}$ berdasarkan tabel MPN dengan ragam 3 tabung. Nilai didapat dari uji presumtif, konfirmatif dan komplek. Semua tabung positif dari MCB dilanjutkan ke ECB. Sedangkan positif ECB akan di kultur ke media EMB. Hasil positif
E. coli dibaca nilainya menggunakan tabel MPN. Sedangkan persyaratan yang ditetapkan oleh SNI no. 7388 tahun 2009 adalah $<3$ MPN/mL, artinya sampel minuman yang mengandung es batu tidak memenuhi syarat kesehatan sesuai yang ditetapkan Kepmenkes RI nomor 942/Menkes/SK/VII/2003.

$S$. aureus merupakan kuman flora normal kulit dan selaput lendir manusia, meskipun begitu bakteri ini dapat menimbulkan infeksi. $S$. aureus ini sering ditemukan pada makanan dengan kandungan protein yang tinggi seperti produk yang mengandung telur dan daging (Menteri Kesehatan, 2003).

Keracunan yang disebabkan adanya S. aureus dalam makanan berhubungan erat dengan kebersihan penjamah dalam mengolah, penyimpanan dan menyajikan makanan menjadi faktor penyebab utama, karena berhubungan dengan keberadaan bakteri ini di permukaan kulit dan selaput lendir. Bakteri ini menghasilkan enterotoksin dalam makanan dan dapat menyebabkan gastroenteritis dan inflamasi pada saluran usus (Pelczar et al, 2014).

Salmonella dan B.cereus merupakan dua mikroorganisme yang tidak ditemukan dalam penelitian ini. Meskipun begitu pengawasan sampel makanan terutama jajanan anak sekolah pada kedua bakteri ini tetap harus dilakukan, karena kedua kuman ini termasuk penyebab keracunan asal makanan.

Keberadaan Salmonella dalam makanan dipengaruhi oleh bahan baku, air, dan kebersihan lingkungan. Masuknya Salmonella ke dalam makanan dan minuman dapat juga melalui kontaminasi silang dalam penyimpanan makanan dan penularan melalui hewan percobaan (Irianto, 2006)). Selain itu keberadaan Salmonella dalam jajanan berhubunganjuga dengan posisi kantin yang berada di dekat parit dan dekat sampah, makanan yang dijajakan tidak tertutup, dan pedagang tidak mencuci tangan terlebih dahulu saat akan menyajikan makanan (Marhamah et al., 2014).

Baik buruknya sanitasi kantin sekolah ditentukan dari jarak sumber pencemar, tempat sampah, dan keberadaan vektor. Keberadaan jarak sumber pencemar berhubungan erat dengan kontaminasi Salmonella (Kumalasari et al., 2013). Bahan baku meliputi air dan bahan dasar pangan yang digunakan, sanitasi, peralatan, 
tindakan higiene pedagang, dan pengolahan juga berhubungan dengan keberadaan bakteri ini dalam jajanan (Kumalasari et al., 2013).

\section{SIMPULAN}

1. Dari hasil pemeriksaan pada jajanan anak sekolah di Kecamatan Koto Tangah ditemukan E. coli dan S. aureus. Sedangkan B. cereus dan Salmonella tidak ditemukan.
Adanya bakteri pengkontaminan dalam makanan dapat menyebabkan keracunan makanan karena bakteri tersebut menghasilkan toksin.

2. Adanya bakteri patogen pengkontaminan pangan jajanan anak sekolah walaupun tidak menimbulkan penyakit tetap akan menurunkan kualitas pangan jajanan anak sekolah tersebut.

\section{DAFTAR PUSTAKA}

Badan POM RI. 2013. Pedoman Pangan Jajanan Anak Sekolah Untuk Pencapaian Gizi Seimbang. Jakarta: Badan POM RI.

Kumalasari, C. R., Martini, P., dan Susiana. 2017. "Hubungan Sanitasi Dengan Status Bakteriologi Koliform Dan Keberadaan Salm0nella Sp Pada Jajanan Di Sekolah Dasar Wilayah Kecamatan Tembalang, Semarang." Aplikasi Tekhnologi Pangan 6 (1): 19-22.

Depkes RI. 2010. Laporan Nasional Riset Kesehatan Dasar ( Riskesdas ). Jakarta: Depkes.

Irianto, K. 2006. Mikrobiologi Menguak Dunia Mikrobiologi. Bandung: CV.Yrama Widya.

Jawetz, Melnick. and Adelberg. 2008. Mikrobiologi Kedokteran. Jakarta: EGC.

Menteri Kesehatan. 2003. Keputusan Menteri Kesehatan Nomor 942/Menkes/SK/VII/2003. Indonesia.

Kuswiyanto. 2017. Bakteriologi 2 Buku Ajar Analis Kesehatan. Jakarta: EGC.

Majumdar, A., Neha, P., Jibin, S., Ananya, A., Nupur, O., Swathy, B., Sutapa, B. 2018. Microbial Contamination And Food Degradation. India: Indian Institute of Science Education and Research (IISER).

Marhamah, Huda, dan Misbahul. 2014. "Kualitas Mikrobiologi Minuman Jajanan (Es, Sirup) Pada Kantin SD Negeri Di Wilayah Kota Bandar Lampung." Analis Kesehatan 3 No.1: 321-26.

Mirawati, M. Lestari, E., dan Djajaninggrat, H. 2014. "Identifikasi Salmonella Yang Dijual Di Kantin Dan Luar Kantin Sekolah Dasar.” Jurnal Ilmu dan Tekhnologi Kesehatan 1: 141-47.

Okolie, N.P, Omonigbehin, E. , Badru, O, A. And Akande, I.S. 2012. "Isolation of Pathogenic Bacteria from Some Foods Sold at Selected Private School in Akoka Area of Yaba Lagos." African journal of Food Science 6: 65-69.

Pelczar, Michael. E.C.S., dan Chan. 2014. Dasar-Dasar Mikrobiologi 2. Jakarta: UI-Press.

SNI. 2009. "Batas Maksimum Cemaran Mikroba Pangan."

Susanna, D dan Hartono, B. 2003. ““ Pemantauan Kualitas Makanan Ketoprak Dan Gado-Gado Di Lingkungan Kampus UI Depok Melalui Pemeriksaan Bakteriologi “.” Makara Seri Kesehatan 7 (1): 21-29.

Vitria, E., dan Deni, A. 2013. "Hubungan Hygiene Sanitasi Dan Cara Pengolahan Mie Ayam Dengan Angka Kuman Di Kota Padang." Kesehatan Masyarakat 7.

Yunaenah. 2009. “Kontaminasi E. coli Pada Makanan Jajanan di Kantin Sekolah Dasar Wilayah Jakarta Pusat Tahun 2009 “. Tesis Fakultas Kesehatan Masyarakat.

WHO. 2004. "Diagnosis and Management of Foodborne Illnesses." In America: American Medical Association. 